\title{
HORTICULTURAL PLANT BREEDING IN THE NETHERLANDS
}

\author{
O. BANGA \\ Institute of Horticultural Plant Breeding, Wageningen, Netherlands \\ Received 27 Nov. 1956
}

\section{Professional BACKGROUND}

Plant breeding has always had a very close connection with the growing of plants. To be successful a variety must be adapted to the cultural methods used and to the natural conditions under which they are being practised.

In the horticultural field this connection between breeding and culture is all the more important because the cultural methods are so much more specialized and based on the individual treatment of plants than in the agronomic sphere, and because the satisfaction a variety gives is based on a more complicated pattern of characters.

Therefore, it is not surprising that the empirical skill and experience of growers has for a long time been the safest guide in horticultural plant breeding, and that, originally, successful new varieties were produced mostly in horticultural centres by growers or by plant breeders closely associated with them.

From the 16th century horticulture developed relatively early and rapidly in the Netherlands. In the vegetable and ornamental growing areas a great number of highly improved varieties were produced. Fruit breeding also was practised. Individual nurserymen and fruitgrowers sometimes found new varieties, but societies of professional growers or of amateurs also took part in the production and selection of new seedlings.

This is the professional background of horticultural plant breeding in the Netherlands, and, I think, in most other countries.

\section{INCORPORATION OF SCIENCE}

Now, in the last ten or twenty years, we have been living in a kind of accelerated phase of evolution, caused by the effort to incorporate science in horticultural plant breeding. Empirical experience of growers is still the most important guide to what is required in a variety, but the importance of analytical research methods is increasing.

I might sketch the present situation as follows.

\section{Vegetables}

In the growing centres many important basic types have been developed. In the past a number of successful breeders among growers have become seed merchants operating a seed trade and selection company. Their main business used to be selection for maintenance and seed distribution, but there are also examples of purposeful breeding of new varieties that gave new opportunities to the vegetable growing industry. I might mention the Long Standing Bloomsdale spinach of A. R. ZWAAN \& Sons, which considerably extended spinach growing in the southern states of the U.S.A., and their pithiness-resistant Cherry-Belle radish, which is being used all over the world now as a radish variety that can be shipped over long distances without becoming pithy. I could 
mention other companies as well, for hardly any have completely lost the enthusiasm of their founders to raise new forms.

At present these establishments tend to make increasing investment in their breeding departments. They are in the process of incorporating more scientific apparatus and more scientifically trained men in their work. And, gradually, they are turning more or less from the old-style selection-companies into scientifically controlled breeding establishments. But the seed trade must proceed cautiously. Many problems arise from the fact that growers' empirical experience cannot yet fully be replaced by science, from the fact that a vegetable breeder still has so many small crops to look after, and from the fact that the sale of vegetable seeds has very restricted possibilities. However, the seed companies still wish to play their part in the development of new varieties, and in general, they wish to do this with the government institutions providing a background of fundamental research.

\section{Fruit crops}

Only in the small-fruit crops, like currants and strawberries, are there some commercial private breeders. In the large-fruit crops there may be some amateur private breeders, but for a commercial concern it is generally considered that serious breeding work is too costly in relation to the profit that seems possible. The breeding of new varieties of fruit is therefore considered a regular task for our Institute of Horticultural Plant Breeding. Other organizations of the Ministry of Agriculture also take part in it.

\section{Ornamentals}

The breeding of ornamentals is almost completely in the hands of the private companies. For the breeding research and the fundamental breeding work of the Boskoop ornamentals in close cooperation with growers, a research-worker of the Institute of Horticultural Plant Breeding has been stationed at the local experimental station at Boskoop.

For the breeding research of the other ornamentals there is a research-worker at our Institute at Wageningen. Most problems are in the field of flower biology (morphology and cytology of flowers and physiology of sexual reproduction).

\section{SCIENTIFIC BACKGROUND}

To effect the breeding work in horticultural plants, the government has founded a number of research institutions. The Institute of Horticultural Plant Breeding at Wageningen is the central Institute. It may station research-workers at local experimental stations. At the Institute for Phytopathological Research at Wageningen a department of disease resistance has been established.

Furthermore, teaching or extension instititions may take part in the work.

I have said that the growers' experience cannot yet fully be replaced by science. We still lack a lot of systematic knowledge in this respect. Therefore, one of the main projects in the research programme of the Institute of Horticultural Plant Breeding is the analysis of the cultural value of plants. In our phytotron we study not only the equilibrium between the vegetative and the generative development of plants, but also the controlling factors in the equilibrium between different vegetative phases or between 
different generative phases. In combination with field tests and chemical investigations this work is very promising.

Of course, the work of the resistance department of the Institute for Phytopathological Research is also of the utmost importance for the improvement of the cultural value of plants.

A second large-scale project, or group of projects, lies in the field of flower biology, or sexual reproduction. In general a better control of the crossings between plants that are difficult in this respect is aimed at. Morphological, cytological and physiological investigations are involved.

Furthermore, there are projects on better control of the periodicity of the plants, on breeding methods, asexual reproduction, etc.

And the basis of all is a systematic study of the varieties and the initial material.

All this work is being done to provide fundamental knowledge.

Another important problem for commercial breeders is how to make their investments profitable.

One answer might be to find a way how to monopolize the results of breeding work. This can be realized in two ways: on the basis of a law, or by breeding hybrid varieties.

It is legally possible to obtain a kind of plant patent on a new variety in the Netherlands, but only for identifiable units.

Breeding hybrid varieties, in particular of heterogamous plants, may provide a monopoly, but only as long as the components of the hybrid variety are kept a secret. Therefore, the breeder should not be obliged to send in the components of his hybrid variety separately before he can get permission to introduce his hybrid variety, as is compulsory in some countries.

\section{SUMMARY}

Since the 16th century horticulture developed relatively early and rapidly in the Netherlands, and in the growing centres of vegetables and ornamentals a great number of highly improved varieties were produced by professional growers. A number of new fruit varieties was raised by professional men or by amateurs.

During the last ten or twenty years science is being incorporated more and more into horticultural plant breeding. In ornamentals and vegetables this takes the form of cooperation between professional breeders and scientific institutions, in fruit the breeding work is mainly done by institutions.

\section{SAMENVATTING}

\section{Veredeling van Tuinbouwgewassen in Nederland}

Sinds de 16e eeuw heeft in Nederland een betrekkelijk vroege en snelle ontwikkeling van de tuinbouw plaats gevonden. In de teeltcentra van groente- en siergewassen is door vakmensen een groot aantal sterk verbeterde rassen gekweekt. Een aantal nieuwe rassen van fruitgewassen werd gewonnen door vakmensen of door amateurs.

Gedurende de laatste tien of twintig jaar begint de wetenschap in het veredelingswerk een steeds grotere rol te spelen. Bij siergewassen en groente neemt dit de vorm aan van een samenwerking van vak-kwekers en onderzoekinstituten, bij fruit gaat het veredelingswerk overwegend bij instituten berusten. 


\section{RASSENLIJSTEN ${ }^{1}$ ) \\ UITGEGEVEN DOOR HET INSTITUUT VOOR DE VEREDELING VAN TUINBOUWGEWASSEN}

Negende Beschrijvende Rassenlijst voor Groentegewassen. 1957. Redacteur Dr. O. Banga . . . $f 1.75$ Achtste Beschrijvende Rassenlijst voor Fruitgewassen. 1957 . . . . . . . . . . . . . . . f1.75

\section{PUBLIKATIES VAN HET INSTITUUT VOOR DE VEREDELING VAN TUINBOUWGEWASSEN IN ANDERE ORGANEN OF IN BOEKVORM EVENTUEEL IN SAMENWERKING MET ANDERE INSTELLINGEN}

De publikaties, waarvan prijs èn uitgever worden vermeld, zijn verkrijgbaar in de boekhandel. Overigens wende men zich tot de opgegeven bronnen of tot de bibliotheek van het I.V.T.

Gijsbers, J. W. Ruimtebesparing bij de opberging van dia's en negatieven. Meded. Dir. Tuinbouw 19, 1956: $298-300$.

Boom, B. K. Over een verzameling prijscouranten. De Boomkwekerij 11, 1956: 128-129.

Boom, B. K. Een Amerikaan over Boskoop. De Boomkwekerij 11, 1956: 130 .

Huyskes, J.A. Klauwenselectie bij asperges geeft goede resultaten. Boer en Tuinder (Land en Vee) 10, 1956:

no. 482:17.

Banga, $O$. Kweker en overheid in de sector groentezaden. Zaadbelangen 10, 1956: 189-190.

Kho, Y. O. Opbrengstvermindering en kiemkrachtverlaging van wortelzaad als gevolg van aantasting door wantsen. Zaadbelangen 10, 1956: 193-194.

Elzenga, G. Digitalis lanata Ehr. V.N.K.-Nieuws 1956: 167-170 en 193-199.

Andeweg, $\mathbf{J}$. M. Rationalisatie en rassenkeuze. Groenten en Fruit 12, 1956: 111.

Kho, Y. O. en J. P. Braak, Opbrengstyermindering en kiemkrachtverlaging van wortelzaad als gevolg van aantasting door wantsen. Meded. Dir. v. d. Tuinbouw 19, 1956: 440-445.

Kronenberg. H. G. Praktijkproeven met aardbeien in 1956. Groenten en Fruit 12, 1956: 177. De Tuinderij 36, 1956, no. $33: 1-3$.

Floor, J. en P. A. Wezelenburg. Stekken onder plastic. De Boomkwekerij 11, 1956: 174-175.

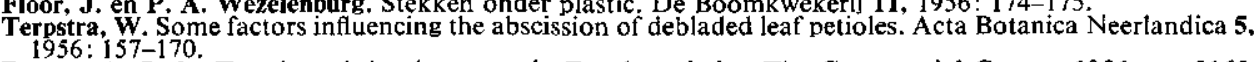

Bruyne, A. S. de. Trends and developments in Dutch varieties. The Commercial Grower 1956, no. 3165 $419-422$.

Smeets, L. A note on the shortening of the juvenile phase in cherry seedlings. Euphytica 5, 1956: 117-118.

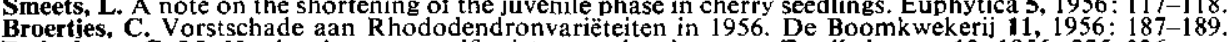

Rodenburg. C. M. Het kweken van wolfresistente spinazierassen. Zaadbelangen 10, 1956: 325-326.

Andeweg. J. M. Een waardevolle vroege kruisingsouder. Zaadbelangen 10, 1956: 344. Huyskes, J. A. en C. M. Rodenburg. Internationale samenwerking bij het onderzoek van slarassen. Meded.
Dir. Tuinb. 19, 1956: 823-826.

Gerritsen, C. J. De teelt van buitenperziken I, II, III, IV. Groenten en Fruit 12, 1956: 537-538; 569-570; $603 ; 628-629$.

Gerritsen, C. J. De Feyoa, een nieuw cultuurgewas? Meded. Dir. Tuinb. 19, 1956: 889-894.

Jensma, J. R. Shuitkoolrassen. Wageningen, I.V.T. 1956: 150 blz. $f 13.50$

Floor, J. Planten in plastic. Wageningen, I.V.T., 1956. f 0.35 .

Eloor, J. Planten in plastic. Wageningen, 1.0 . De teelt van Valeriaan. V.N.K. 1956. f $0.35: 234-236$.

Elzenga, G. Het mechanisch rooien van Valeriaan. V.N.K.-Nieuws 4, 1956: 246

Elzenga, G. Het opkweken van plantmateriaal van Levisticum en Rheum. V.N.K.-Nieuws 4, 1956: 246-247.

Elzenga, G. Roest in munt. Zou gier helpen? V.N.K.-Nieuws 4, 1956:247.

Elzenga, G. Mechanisch planten van Valeriaan blijkt zeer goed mogelijk. V.N.K.-Nieuws 4, 1956: 248-249.

Elzenga, G. De oogstdatum van Digitalis lanata. V.N.K.-Nieuws 4, 1956: 249-250.

Giessen, A. C, v, d. en A. v. Steenbergen. Een nieuwe methode voor de toetsing van bonen op resistentie tegen vlekziekte. Zaadbelangen 11, 1957: 26-27.

Huyskes, J. A. Moet Nederland groene en/of vezelvrije asperges gaan telen? Meded. Dir. Tuinb. 20, 1957: 69-75.

Nieuwhof, M. Vegetatieve instandhouding en vermeerdering bij koolgewassen. Zaadbelangen 11, 1957: 93-96.

Kho, Y. O. Nogmaals wantsen en zaadteelt bij wortelen. Zaadbelangen 11, 1957: 78-79.

Andeweg, J. M. en A. van Steenbergen. Praktijkproeven met tuinbonen. Meded. Dir. Tuinb. 20, 1957: 133139.

Wassenaar, L. M. Is het mogelijk het aardbeiras Climax door selectie toch vrij te houden van voorjaarsbont? Groenten en Fruit 12, 1957:1064.

Andeweg, J. M, Komkommerhybriden. Zaadbelangen 11, 1957: 127.

Rodenburg, C. M. Het herkennen van slarassen aan de jonge plant. Groenten en Fruit 12, 1957: 1130-1131.

1) Zolang de voorraad strekt kunnen deze publikaties franco worden toegezonden, na ontvangst van het vermelde bedrag op giro no. 425340 van het Instituut voor de Veredeling van Tuinbouwgewassen, $D r$. $S$. L Mansholtlaan 15 te Wageningen onder vermelding van wat verlangd wordt; ook bestaat de mogelijkheid deze publikaties uit de bibliotheek van het I.V.T. te lenen. 